\title{
Czynniki uaktywniające i zróżnicowanie czasowe przemieszczeń koluwiów w różnych częściach stoku osuwiskowego - analiza dendrochronologiczna na przykładzie osuwiska Skalka (Moravskoslezské Beskydy)
}

\author{
Triggering factors and temporal variability of colluvium movements within \\ a landslide slope - dendrochronological analysis at the example of Skalka landslide \\ (Moravskoslezské Beskydy)
}

\begin{abstract}
Katarzyna Łuszczyńska, Małgorzata Wistuba
Katedra Rekonstrukcji Środowiska Geograficznego, Wydział Nauk o Ziemi, Uniwersytet Śląsi w Katowicach, Sosnowiec; email: katarzyna_luszczynska@o2.pl
\end{abstract}

Zarys treści: Celem badań było określenie zmienności czasowej osuwania i stwierdzenie różnic w aktywności poszczególnych części stoku osuwiskowego. Zastosowano metody dendrochronologiczne: dla 60 świerków pospolitych analizowano dekoncentryczność przyrostów rocznych. Największą dynamikę osuwania stwierdzono w latach: 1975, 1993, 1985, 1968-1969, 1995. Liczba zaburzeń wzrostu radialnego drewna świadczących o osuwaniu w poszczególnych latach dobrze odpowiada przebiegowi sum opadów półrocza letniego (np. osuwanie i opady w latach: 1968, 1972, 1975, 1977, 1985, 2010) oraz w mniejszym stopniu zimowego. Wyniki wskazują na nierównoczesną aktywność poszczególnych części osuwiska i uruchamianie różnych jego partii podczas różnych epizodów opadowych oraz prawdopodobnie w efekcie innych czynników uaktywniających (np. trzęsień ziemi z lat 1992-1993 o epicentrach w Beskidzie Sądeckim).

Słowa kluczowe: dendrochronologia, osuwanie, dekoncentryczność wzrostu, świerk pospolity, Moravskoslezské Beskydy

\begin{abstract}
The aim of the study was to determine the temporal variability o landsliding and differences in the activity of individual part of a small landslide. Dendrochronological methods have been applied: tree-ring eccentricity was analysed for 60 Norway spruce trees. The most dynamic landsliding occurred in: 1975, 1993, 1985, 1968-1969 and 1995. The number of wood-growth disturbances recording landsliding in particular years matches well with precipitation totals for summer half-years (e.g. landsliding and precipitation in: 1968, 1972, 1975, 1977, 1985, 2010) and to the smaller degree with totals for winter half-years (e.g. 1961). Results indicate uneven activity of particular landslide sections. The movement in particular parts of the landslide is triggered during various precipitation events or due to other factors (e.g. 1992-1993 earthquakes with epicentres in Beskid Sądecki Mts).
\end{abstract}

Key words: dendrochronology, landsliding, growth eccentricity, Norway spruce, Moravskoslezské Beskydy

\section{Wstęp}

Osuwanie jest jednym z najbardziej powszechnych procesów geomorfologicznych w Karpatach fliszowych (Bajgier-Kowalska 1994, Margielewski 1997, Gorczyca 2010, Šilhán 2012). Szczególnie podatne na osuwanie są obszary, gdzie występują kompleksy piaskowców i pokrywy stokowe podścielone łupkami (Gorczyca 2008). Ze względu na zagrożenie stwarzane przez aktywne osuwiska (Klimeš i in. 2009, Pánek i in. 2011b, Klimeš, Blahůt 2012) rozpoznanie i monitoring osuwisk stale i okresowo aktywnych jest współcześnie jednym z najważniejszych zadań, podejmowanych w geomorfologii i geologii (Krąpiec i in. 2008). Dobrą metodą służącą do określenia dynamiki przebiegu procesów na stokach niezabudowanych, zalesionych, podobnych do badanego, są metody 
dendrochronologiczne (Wistuba $\mathrm{i}$ in. 2014). Tylko dendrochronologia może dostarczyć informacji o przebiegu przeszłych zdarzeń rzeźbotwórczych, w tym osuwania (Schweingruber 1996), których ślady są zapisane w przyrostach drzew (Braam i in. 1987, Lang i in. 1999, Malik 2008). Drzewa, które rosną na obszarze objętym procesami rzeźbotwórczymi podlegają stresowi środowiskowemu (Malik 2008), zapisującemu się w drewnie w postaci np. redukcji rocznych przyrostów, dekoncentryczności wzrostu, drewna reakcyjnego, blizn po ranach lub kanałów żywicznych (Shroder 1980, Schweingruber 1996). Datując pierwszy, najstarszy rok pojawienia się wymienionych zaburzeń anatomicznych w drewnie, pośrednio datuje się również epizod rzeźbotwórczy, który do nich doprowadził.

W badaniach zdarzeń osuwiskowych jedną z kluczowych przesłanek jest zrozumienie mechanizmów uaktywniających, które je wyzwalają (Corominas, Moya 2008). Metody dendrogeomorfologiczne, ze względu na wysoką (roczną) rozdzielczość uzyskiwanych wyników rekonstrukcji przebiegu osuwania są narzędziem szczególnie przydatnym $\mathrm{w}$ analizie takich czynników uaktywniających jak: opady atmosferyczne (np. Krąpiec, Margielewski 1991, Krąpiec i in. 2008, Pánek i in. 2011a, Papciak i in.2015), trzęsienia ziemi (np. Šilhán i in. 2012) czy erozja boczna cieków (np. Wistuba i in. 2013a, Šilhán i in. 2014, Wistuba $i$ in. 2015).
W datowaniach dendrochronologicznych osuwania najczęściej wyniki datowań dla bardzo rozległych form (uzyskane czasem nawet dla kilkuset drzew ) analizowane są wspólnie, jako całość. Przez to nie jest wykorzystywany podstawowy walor metody, jakim jest możliwość uzyskania kompleksowej, szerokiej informacji o przebiegu osuwania w przeszłości. Część epizodów osuwania, które nie objęły swoim zasięgiem całej analizowanej formy może pozostać niezauważona, zamaskowana przez wyniki z reszty powierzchni osuwiska. Przy tym dla wielu osuwisk zaobserwowano dużą przestrzenną zmienność przebiegu osuwania (Lopez Saez i in. 2012), reaktywację jedynie części ich powierzchni w czasie jednego epizodu (np. Pánek i in. 2011b) a także oddziaływanie różnych czynników uaktywniających w obrębie jednego stoku (Šilhán i in. 2012, Wistuba i in. 2015). Celem badań prowadzonych na stoku góry Skalka w Moravskoslezských Beskydach była analiza dynamiki ruchu niewielkiego osuwiska, obejmująca określenie zmienności czasowej osuwania, a w szczególności stwierdzenie różnic w aktywności poszczególnych części badanej formy.

\section{Teren badań}

Obszar badań zlokalizowany jest w Moravskoslezských Beskydach, górach średnich będących częścią Karpat
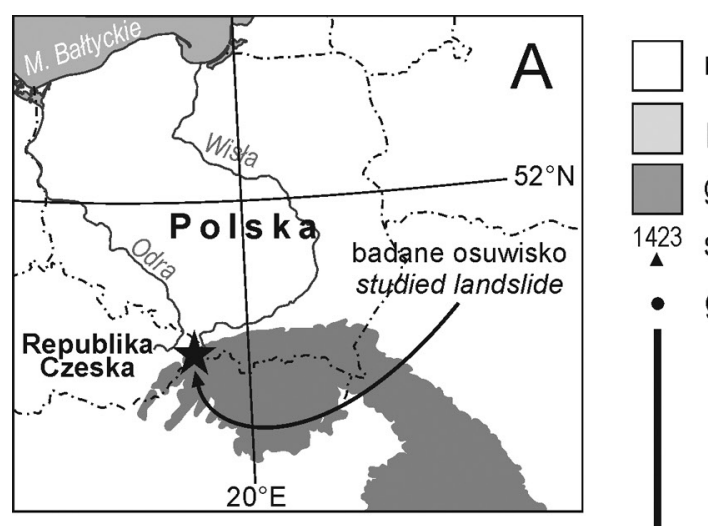

niziny i wyżyny lowlands and uplands

pogórza forelands

góry niskie i średnie low and mid-height mountains

423 szczyty górskie (m n.p.m.) mountain peaks ( $m$ a.s.l.)

- główne miejscowości main towns
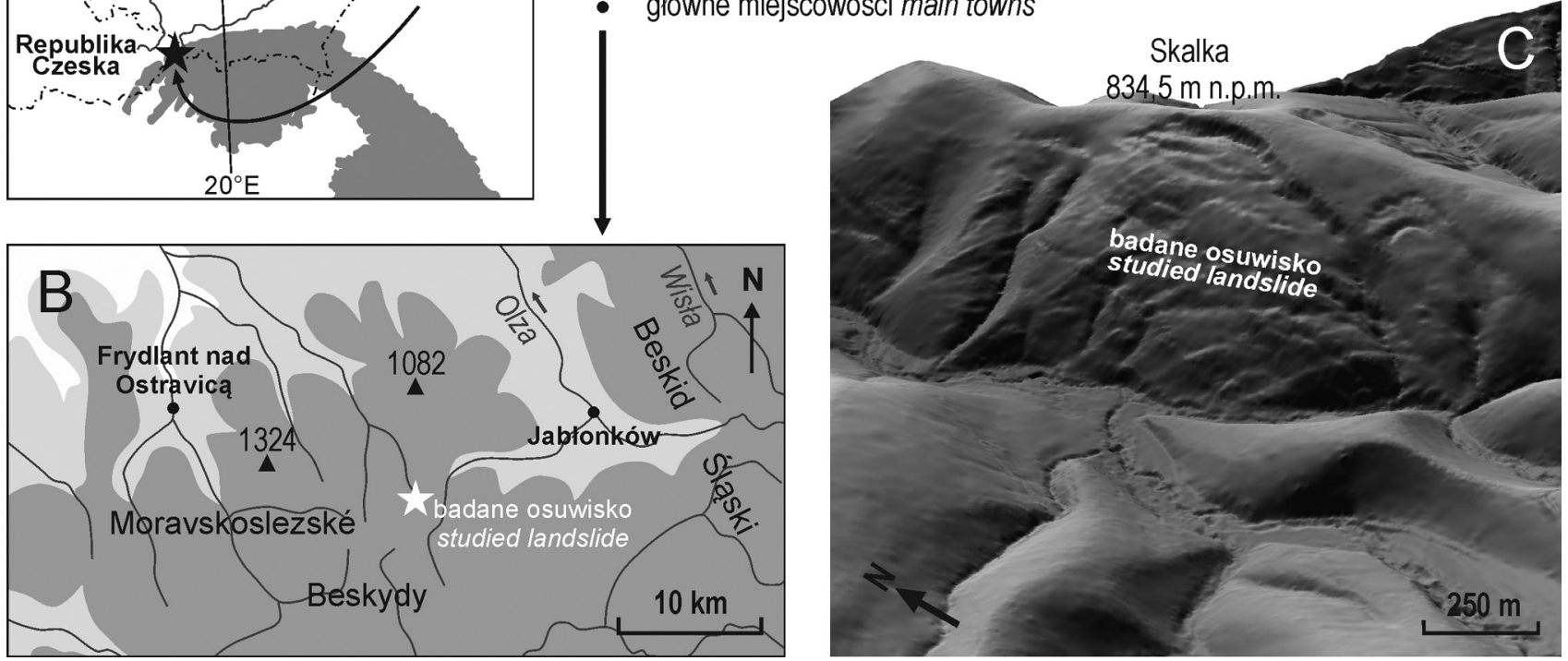

Ryc. 1. Położenie badanego osuwiska w Karpatach (A), w Moravskoslezských Beskydach (B) i na zboczu doliny potoku Skalka (C) (na podstawie danych LiDAR: cyfrowego modelu terenu Republiki Czeskiej czwartej generacji (4G DMR), Český úřad zeměměřický a katastrální)

Fig. 1. Location of the studied landslide in the Carpathian Mts. (A), in Moravskoslezské Beskydy (B), and on a slope of the Skalka Stream valley (C) (based on LiDAR data: digital terrain model of the Czech Republic 4th generation (4G DMR), Český úrad zeměměřický a katastrální) 


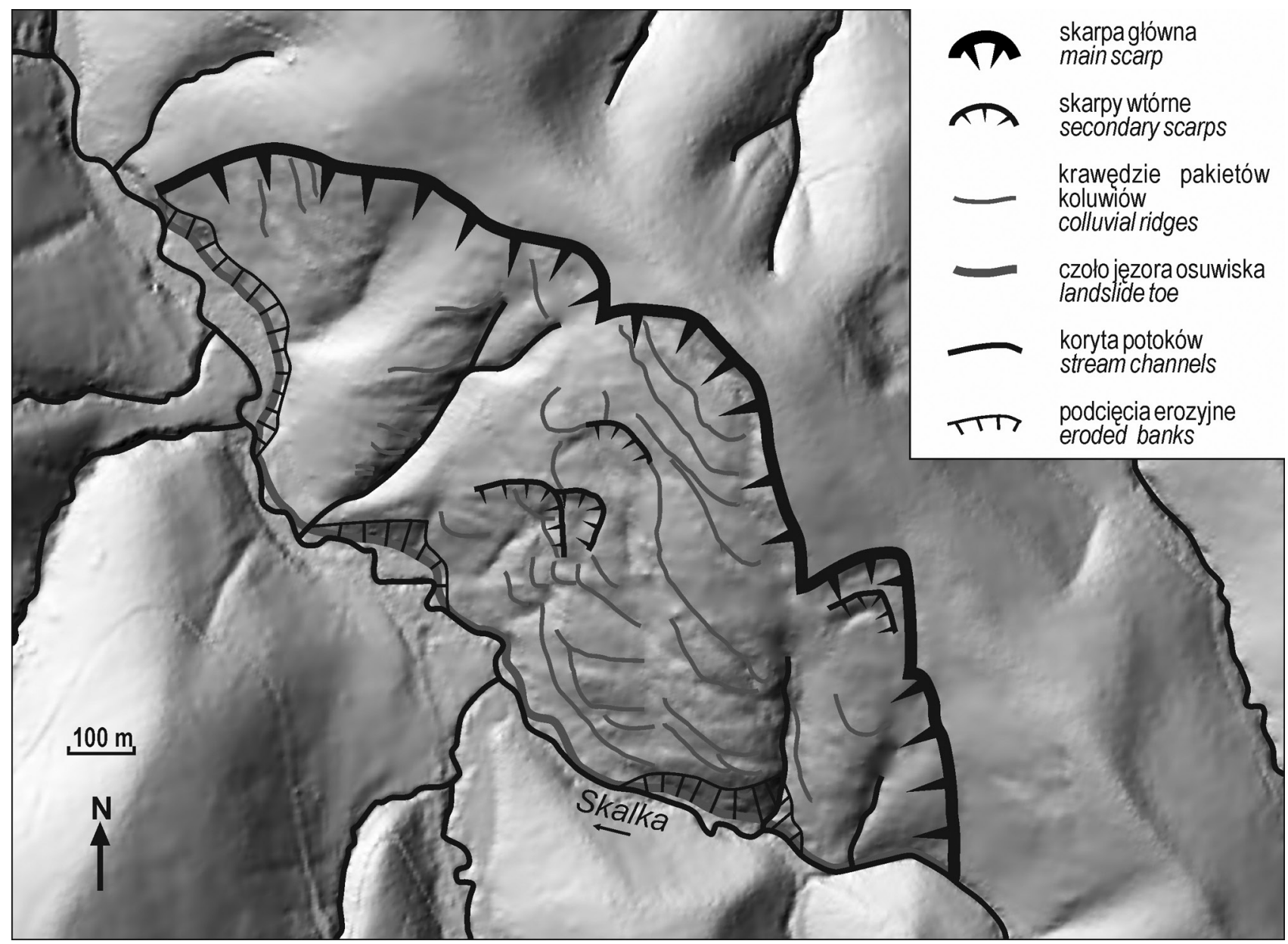

Ryc. 2. Rzeźba badanego stoku osuwiskowego (mapa cieniowana na podstawie danych LiDAR: cyfrowego modelu terenu Republiki Czeskiej czwartej generacji (4G DMR), Český úřad zeměměřický a katastrální)

Fig. 2. Relief of the studied landslide slope (shaded relief map based on LiDAR data: digital terrain model of the Czech Republic 4th generation (4G DMR), Český úřad zeměměřický a katastrální)

Zachodnich (Ryc. 1A). Do badań wytypowano osuwisko położone na stoku góry Skalka (834,5 m n.p.m.) w południowo-wschodniej części Moravskoslezských Beskydów (Ryc. 1B). Osuwisko leży na wysokości 650-828 m n.p.m. Zostało wykształcone w obrębie warstw godulskich: cienko- i średnioławicowych warstw łupków i piaskowców, miejscami silnie mułowcowych (Interactive... 2003), lokalnie pod pokrywą czwartorzędowych aluwiów oraz osadów stokowych, w tym koluwiów osuwiskowych (Interactive... 2003).

Stanowisko badawcze leży w piętrze klimatycznym umiarkowanie chłodnym (Hess 1965). Moravskoslezské Beskydy cechuje bardzo częste występowanie ekstremalnych dziennych sum opadów atmosferycznych ( $\geq 150 \mathrm{~mm}$ na dobę) (Štekl i in. 2001). Średnia roczna suma opadów w obszarze badań sięga 1423,8 mm (Lysá hora 1324 m n.p.m.). Badany obszar leży w obrębie regla dolnego, gdzie naturalnym zbiorowiskiem leśnym są lasy z bukiem zwyczajnym (Fagus sylvatica L.) i jodłą pospolitą (Abies alba Mill.) (Seneta, Dolatowski 2008). Stanowisko badawcze porasta jednak w większości las świerkowy, co wynika z działalności człowieka. Dolnoreglowe lasy mieszane w efekcie gospodarki leśnej zastąpiono nasadzeniami świerków pospolitych. Osuwisko jest w całości zalesione, głównie przez drzewostan młody (przeważają drzewa wieku 50-60 lat).

Badane osuwisko (1 $250 \mathrm{~m}$ szerokości, $545 \mathrm{~m}$ długości) posiada pięć skarp osuwiskowych, w tym cztery wtórne, częściowo o zatartej rzeźbie (Ryc. 2). Poniżej skarpy głównej (długość: 1900 m, wysokość: 25 m) rozciąga się jęzor osuwiskowy o przeciętnym nachyleniu $10^{\circ}$, zbudowany z materiału skalno-zwietrzelinowego, rozczłonkowany przez liczne rozcięcia erozyjne, z wyraźnymi krawędziami pakietów przemieszczonych koluwiów (Ryc. 2). W górnej i środkowej części osuwiska występują cztery skarpy wtórne o długości do $70 \mathrm{~m}$ i wysokości do $18 \mathrm{~m}$ (Ryc. 2). Rzeźba powierzchni badanej formy jest falista i pagórkowata, szczególnie w środkowej części osuwiska (Ryc. 2). Dolna, najsilniej nachylona część jęzora osuwiskowego podcinana jest przez erozję boczną koryta potoku Skalka (Ryc. 1C, 2).

\section{Metody badań}

Dendrochronologiczne datowania występowania osuwania wykonano stosując indeks dekoncentryczności przyrostów rocznych. Dekoncentrycznością wzrostu nazywamy 


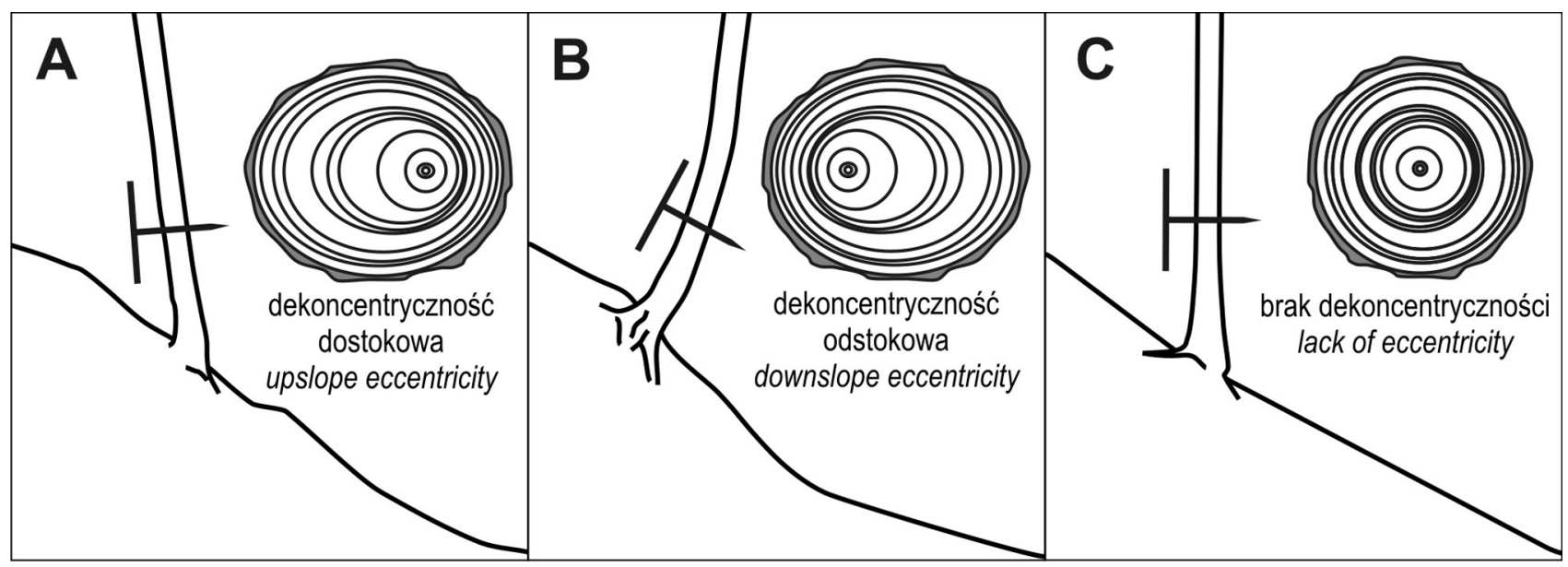

Ryc. 3. Wykształcanie przyrostów dekoncentrycznych w pniach drzew pochylonych dostokowo (A) i odstokowo (B) oraz koncentryczny przyrost drewna w pniach prostych (C) (za: Wistuba, Malik 2011, zmienione)

Fig. 3. Development of eccentric growth in stems of trees tilted upslope (A) and downslope (B), and concentric growth of wood in vertical stems (C) (after: Wistuba, Malik 2011, altered)

tendencję drzewa do wykształcania szerszych przyrostów rocznych w części obwodu pnia (Wistuba, Malik 2011, Wistuba $\mathrm{i}$ in. 2013b). Jednym $\mathrm{z}$ powodów nierównomiernego wzrostu jest stres mechaniczny w pochylonym pniu (Schweingruber 1996). Drzewa rosnące na aktywnych stokach osuwiskowych pochylają się wraz z ruchem podłoża (Ryc. 3). Dostokowe pochylanie pni drzew iglastych wywołuje wykształcanie szerszych przyrostów rocznych po stronie dostokowej (Ryc. 3A), a odstokowe - szer- szych po stronie odstokowej (Ryc. 3B). Na stokach stabilnych występują drzewa o prostych pniach i mniej więcej koncentrycznym wzroście (Ryc. 3C) (Krąpiec, Margielewski 2000, Wistuba, Malik 2011). Analiza przyrostów rocznych pod względem występowania dekoncentryczności pozwala na określenie najbardziej prawdopodobnych momentów ruchu podłoża w przeszłości.

Indeks dekoncentryczności przyrostów rocznych zastosowano dla próbek pobranych ze świerków pospoli-

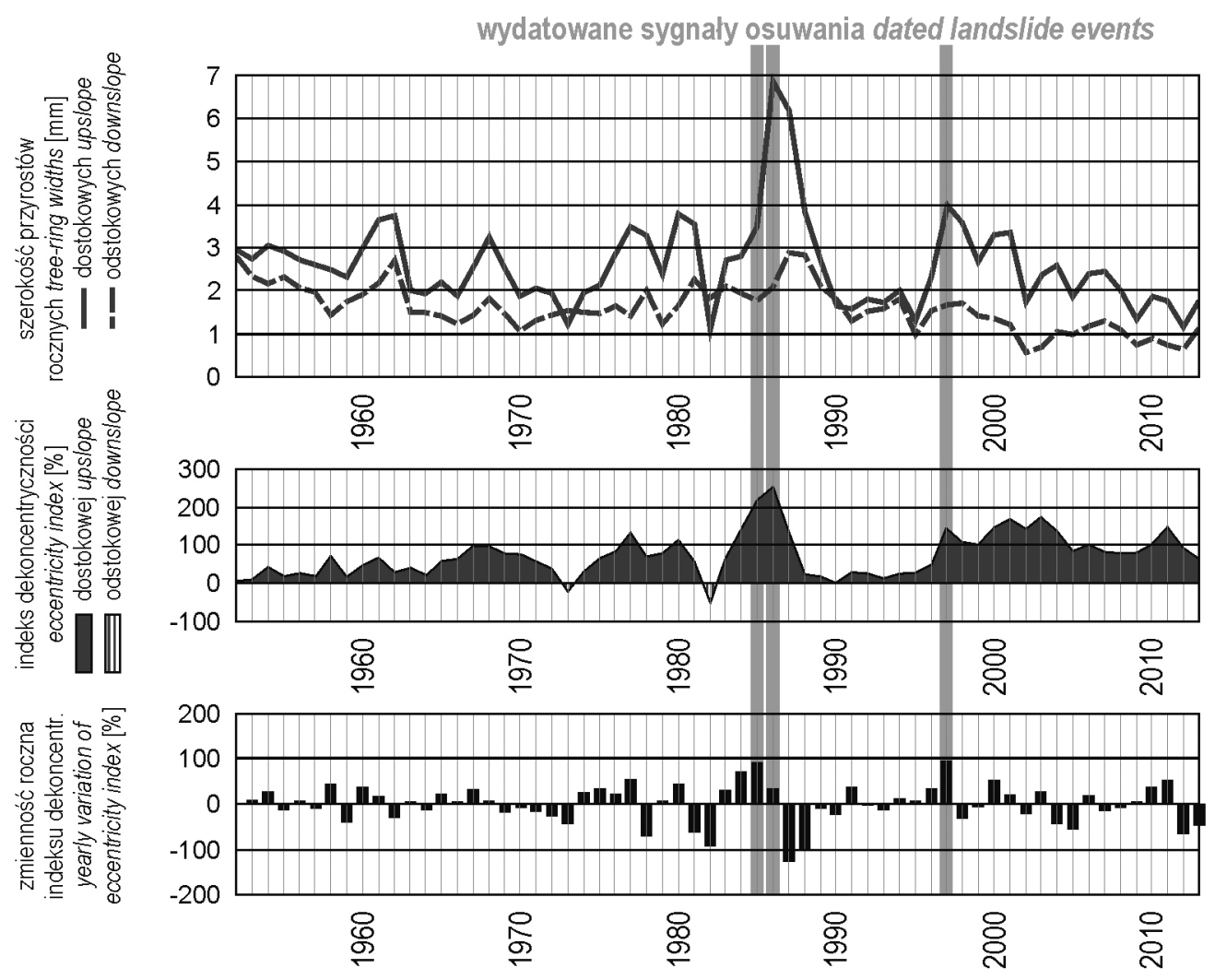

Ryc. 4. Szerokość przyrostów rocznych, indeks dekoncentryczności i jego zmienność roczna w pniu drzewa pochylanego na skutek osuwania podłoża na badanym stanowisku. Epizody osuwania wydatowane w oparciu o dekoncentryczność wzrostu radialnego drzew

Fig. 4. Tree-rings widths, eccentricity index and its yearly variation in a tree stem tilted by landsliding on the studied side. Landslide events dated using eccentric growth of trees 


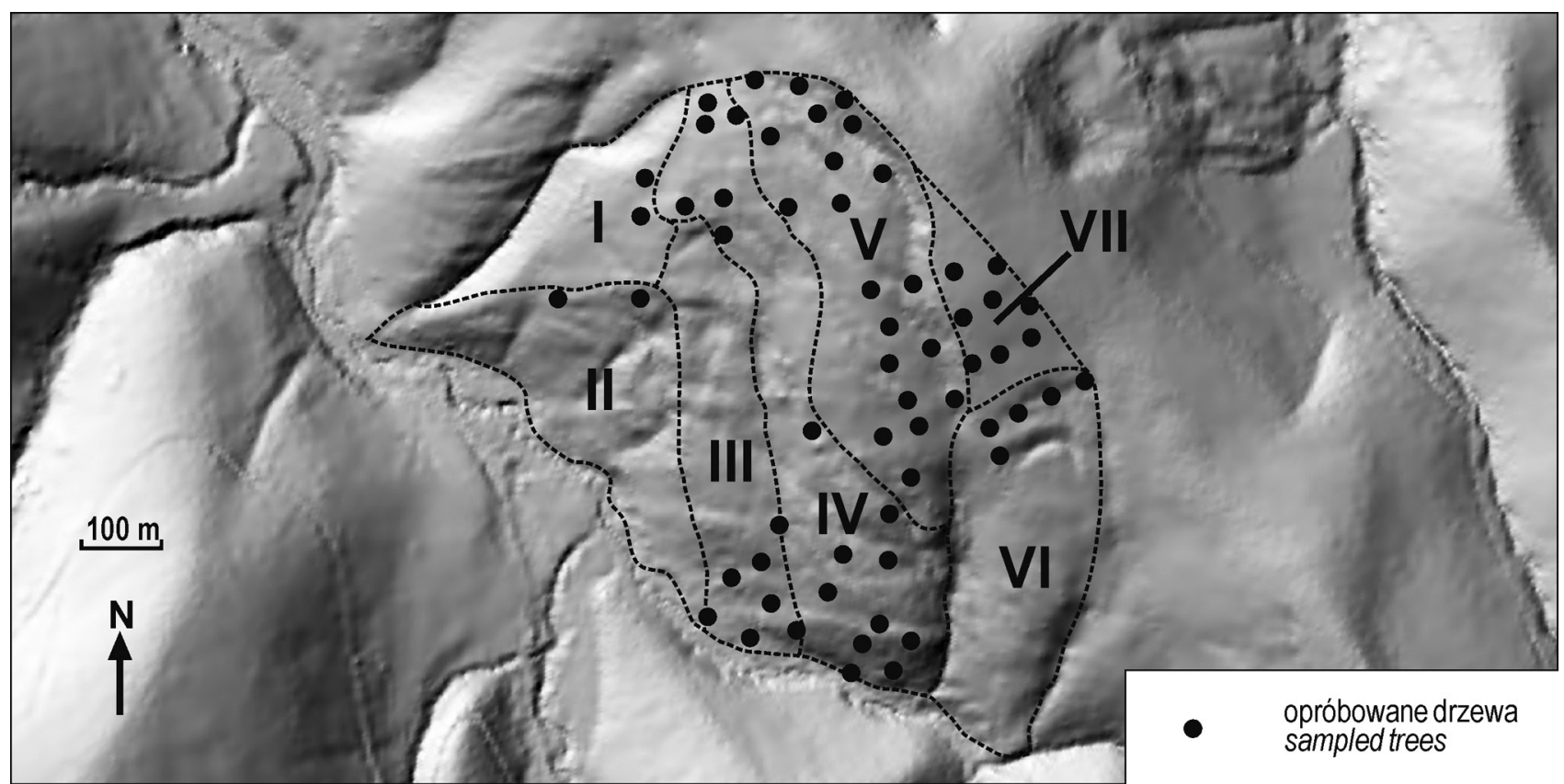

Ryc. 5. Podział badanego osuwiska na strefy morfologiczne oraz lokalizacja opróbowanych drzew (mapa cieniowana na podstawie danych LiDAR: cyfrowego modelu terenu Republiki Czeskiej czwartej generacji (4G DMR), Český úřad zeměměřický a katastrální) Fig. 5. Studied landslide divided into relief zones and the location of sampled trees (based on LiDAR data: digital terrain model of the Czech Republic 4th generation (4G DMR), Český úřad zeměměřický a katastrální)

tych (Picea abies Karst.). Z każdego z 60 drzew pobrano po dwa rdzenie: jeden ze strony dostokowej pnia, drugi z odstokowej. Próbki pobierano standardowym świdrem Presslera, na wysokości pierśnicy, zgodnie z nachyleniem terenu i pochyleniem pni. Do badań wybierano osobniki wizualnie ocenione jako zdrowe. Próbki pobrano głównie w najwyższej i najniższej części osuwiska oraz w mniejszym stopniu w części środkowej. Lokalizacja miejsc opróbowania (Ryc. 5) zależała od dostępności zdrowych świerków w odpowiednio starym wieku (z badań wykluczono podrost młodych drzew o obwodzie mniejszym niż $50 \mathrm{~cm})$.

Pobrane rdzenie wklejono do listew mocujących i zeszlifowano papierem ściernym. Następnie zmierzono szerokość przyrostów rocznych w rdzeniach z dokładnością $0,01 \mathrm{~mm}$. Na podstawie szerokości przyrostów rocznych zmierzonych dla odstokowej i dostokowej strony pni obliczono dekoncentryczność przyrostów, indeks dekoncentryczności oraz jego zmienność roczną (Ryc. 4), według wzorów (Wistuba, Malik 2011, Wistuba i in. 2013b):

$$
\mathrm{E}_{\mathrm{x}}[\mathrm{mm}]=\mathrm{U}_{\mathrm{x}}-\mathrm{D}_{\mathrm{x}}
$$

- gdy $\mathrm{E}_{\mathrm{x}}[\mathrm{mm}]>0$ : dekoncentryczność dostokowa;

$$
\mathrm{I}_{\mathrm{x}}[\%]=\left(\mathrm{E}_{\mathrm{x}} / \mathrm{D}_{\mathrm{x}} \mathrm{x} 100 \%>0\right. \text {; }
$$

- $\operatorname{gdy} \mathrm{E}_{\mathrm{x}}[\mathrm{mm}]=0$ : brak dekoncentryczności;

$$
\mathrm{I}_{\mathrm{x}}[\%]=\mathrm{E}_{\mathrm{x}}[\mathrm{mm}]=0 \text {; }
$$

- gdy $\mathrm{E}_{\mathrm{x}}[\mathrm{mm}]<0$ : dekoncentryczność odstokowa;

$$
\begin{gathered}
\mathrm{I}_{\mathrm{x}}[\%]=\left(\mathrm{E}_{\mathrm{x}} / \mathrm{U}_{\mathrm{x}}\right) \times 100 \%<0 ; \\
\mathrm{V}_{\mathrm{x}}[\%]=\mathrm{I}_{\mathrm{x}}-\mathrm{I}_{\mathrm{x}-1} ;
\end{gathered}
$$

gdzie: U - szerokość przyrostu rocznego po dostokowej stronie pnia [mm]; D - szerokość przyrostu rocznego po odstokowej stronie pnia [mm]; E - dekoncentryczność przyrostu rocznego [mm]; I - indeks dekoncentryczności przyrostu rocznego [\%]; V - zmienność roczna indeksu $[\%]{ }_{x}-$ rok/przyrost roczny.

Epizody osuwania wydatowano z użyciem progów referencyjnych (wartości wskaźników dekoncentryczności typowych dla pobliskiego stoku stabilnego): 53,37\% (dla pochylania dostokowego) oraz $-56,05 \%$ (dla pochylania odstokowego) (za Wistuba i in. 2013a). Wyniki datowań dendrochronologicznych były podstawą analizy czasowej zmienności osuwania na badanym stoku oraz próby określenia roli opadów w jego aktywności. Posłużono się sumami opadów na najbliższej stacji meteorologicznej, która jednocześnie posiada długi okres obserwacji (Lysá hora, $11 \mathrm{~km}$ na W od stanowiska badawczego, dane dla lat 1947-2011) (źródło danych: Česki hydrometeorologicki ústav, Ostrava, Republika Czeska). Na potrzeby analizy zróżnicowania ruchu koluwiów w obrębie badanego stoku osuwiskowego podzielono go na siedem części (Ryc. 5) w oparciu o zróżnicowanie jego rzeźby widoczne na numerycznym modelu terenu (źródło danych LiDAR: cyfrowy model terenu Republiki Czeskiej czwartej generacji (4G DMR), Český úřad zeměměřický a katastrální). Wydzielono:

- I - boczną część jęzora osuwiskowego o gładkiej powierzchni,

- II - stromą, erozyjnie podciętą dolną część jęzora poniżej skarpy wtórnej,

- III - system progów osuwiskowych, pakietów koluwiów poniżej skarpy wtórnej,

- IV - część jęzora o rzeźbie falistej i schodkowym pro- 
filu podłużnym,

- V - górną część jęzora i skarpę główną,

- VI - boczną część jęzora,

- VII - stok powyżej skarpy głównej z oznakami inicjalnego osuwania (szczeliny bezpośrednio ponad skarpą główną).

\section{Wyniki}

\section{Dendrochronologiczny zapis aktywności całego badanego osuwiska}

Sekwencje przyrostów rocznych z drzew opróbowanych na badanym osuwisku sięgają lat 40. XX wieku (Ryc. 6). Większość (40 z 60) sekwencji rozpoczyna się w ciągu ostatnich 65 lat. Najstarszy dendrochronologiczny sygnał ruchów masowych badanego stoku góry Skalka wydatowano na 1949 rok. W okresie 1940-2013 w opróbowanych drzewach łącznie wydatowano 259 sygnałów osuwa- nia. Sygnały osuwania, analizowane dla całości osuwiska, skupiają się głównie w latach: 1965, 1968-1972, 19751977, 1985, 1993-1997, 2004-2008 i 2010 (Ryc. 6). Przez większą część analizowanego okresu (1940-2013) odsetek drzew reagujących na ruch podłoża nie przekracza $10 \%$, co oznacza, że przez ostatnie 75 lat na badanym stoku dominowały słabe epizody osuwania, które obejmowały tylko jego niewielkie części. Najsilniejsze epizody odnotowano w latach 1975 (zareagowało 20,3\% drzew), 1993 (16,7 \%) i 1985 (15\%) (Ryc. 6). Pomiędzy epizodami osuwania występowały okresy względnej stabilizacji, na przykład 1990-1992, czy w mniejszym stopniu 1998-2003 (Ryc. 6). Badane osuwisko było jednak niemal stale aktywne - w ciągu ostatniego półwiecza właściwie brak jest lat, dla których nie stwierdzono dendrochronologicznych sygnałów osuwania.

Wyniki analizy aktywności badanego osuwiska na stoku góry Skalka zostały porównane z przebiegiem sum opadów półrocza letniego (kwiecień-wrzesień, średnia z wielolecia: $891,2 \mathrm{~mm}$ ) i poprzedzającego półrocza

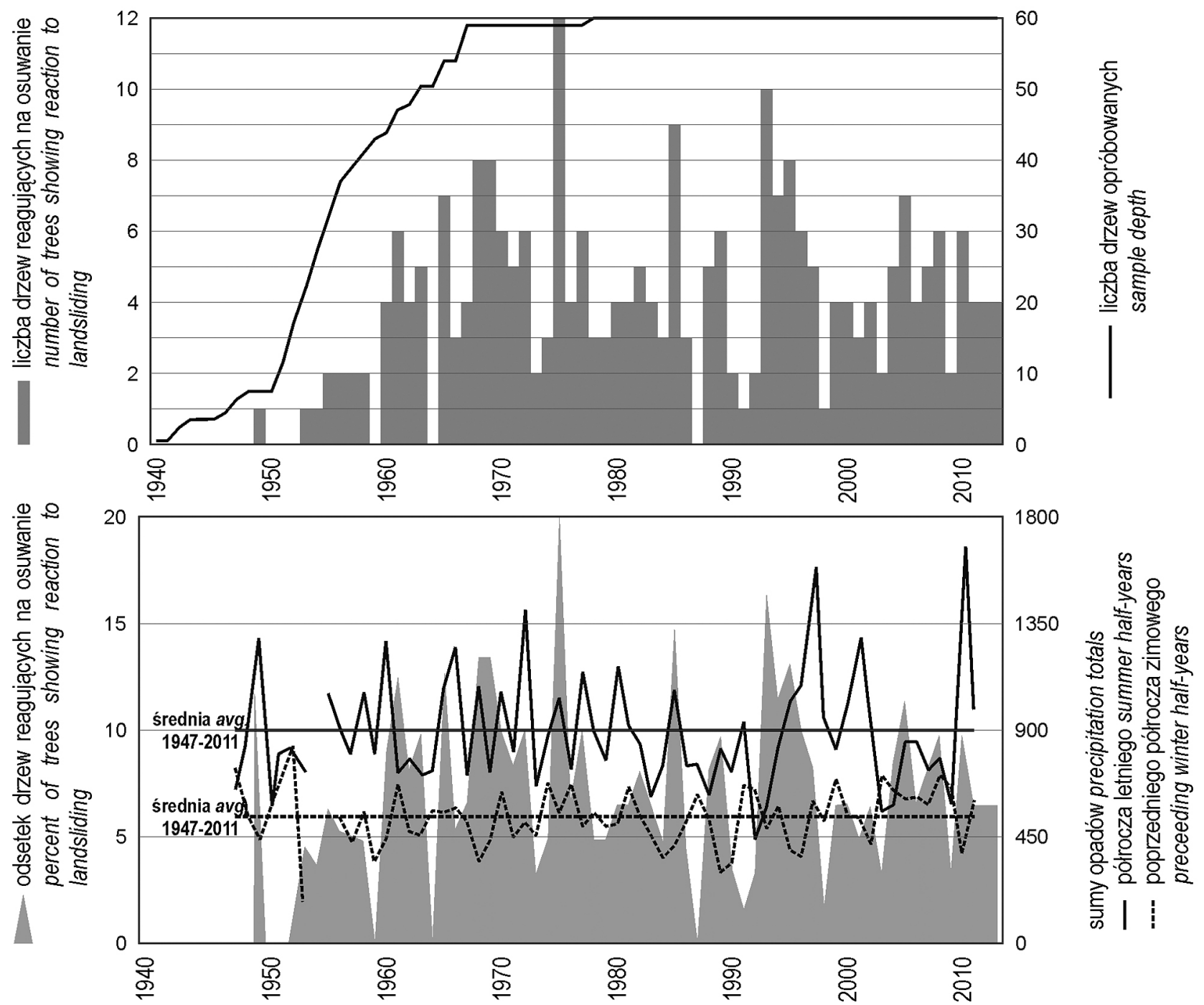

Ryc. 6. Wyniki datowań dendrochronologicznych aktywności badanego osuwiska wraz z przebiegiem opadów półrocza letniego i półrocza zimowego na Lyséj horze

Fig. 6. Results of dendrochronological dating of the studied landslide activity with the precipitation record for summer and winter halfyears on Lysá hora Mt. 


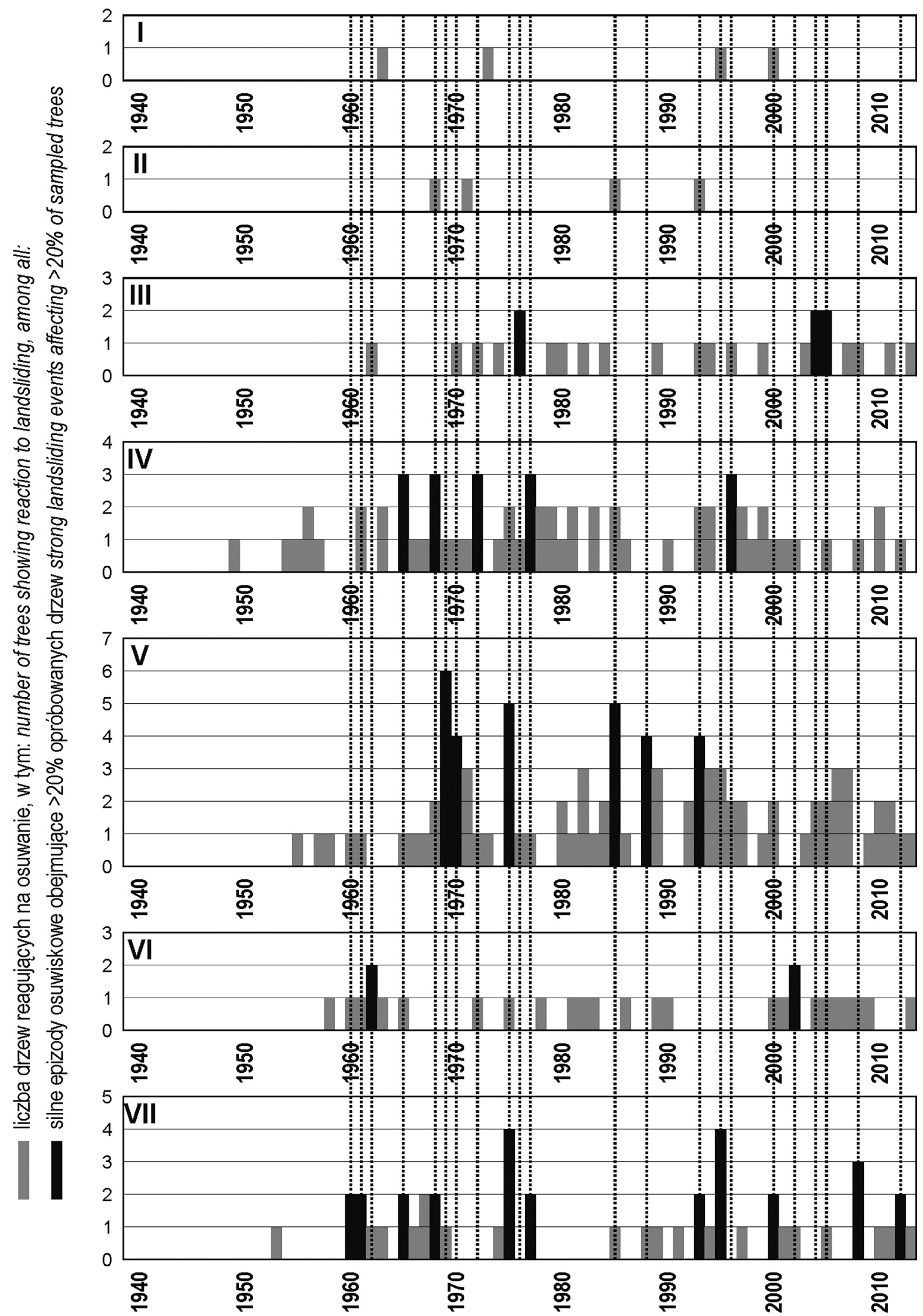

Ryc. 7. Wyniki datowania dendrochronologicznego osuwania uzyskane dla poszczególnych stref morfologicznych badanego osuwiska. Epizody osuwania obejmujące więcej niż jedną strefę zaznaczono przerywanymi liniami pionowymi

Fig. 7. Results of dendrochronological dating of landslide activity obtained for particular morphological zones of the studied landslide. Events comprising more than one morphological zone are marked with dotted lines 
zimowego (październik-marzec, średnia z wielolecia: $533,7 \mathrm{~mm}$ ) zarejestrowanych na stacji opadowej na Lyséj horze w latach 1947-2011. Przykładami wydatowanych sygnałów osuwania, których występowanie pokrywa się w czasie z wysokimi sumami opadów półrocza letniego są na przykład lata: 1965,1968, 1970, 1972, 1975, 1977 , 1985, 1995-1997, 2010 (Ryc. 6). Sygnałów osuwania towarzyszących wysokim sumom opadów poprzedzającego półrocza zimowego jest znacznie mniej (lata: 1961, 1970, 2008). Zarejestrowane na powierzchni badanego osuwiska dendrochronologiczne epizody niestabilności podłoża nie zawsze pokrywają się z wysokimi sumami opadów (np. lata: 1969, 1989, 1993-1994, 2005) (Ryc. 6). Może to świadczyć o oddziaływaniu innych czynników uaktywniających na ruch badanego osuwiska. Należeć do nich może erozja boczna cieku lub trzęsienia ziemi o epicentrach w Karpatach - np. z lat 1992-1993 (Guterch 2009). Efekt tych wstrząsów drzewa zarejestrowały w 1993 roku. Inną przyczyną może być też opóźniona/przedłużona reakcja osuwiska na obfite opady występujące rok wcześniej (np. 1969). Uzyskane wyniki wskazują na lata o wysokich sumach opadów, którym nie towarzyszyły dendrochronologiczne epizody osuwania (np. opady półrocza letniego 1960, 1966, 1980-1981, 2000-2002 czy opady półrocza zimowego 1974, 1987, 1991-1992, 2003, 2009) (Ryc. 6).

\section{Zróżnicowanie aktywności poszczególnych części badanego osuwiska}

W poszczególnych strefach morfologicznych badanego osuwiska opróbowano różną liczbę drzew, co było uwarunkowane przede wszystkim dostępnością osobników odpowiednich do poboru próbek: w strefie I opróbowano 2 drzewa, w strefie II - 2 drzewa, w strefie III - 7 drzew, w strefie IV -16 drzew, w strefie V -20 drzew, w strefie VI - 5 drzew, a w strefie VII -8 drzew. Ze względu na małą liczbę opróbowanych drzew z dalszej analizy wyłączono strefy I i II. Analiza wyników datowania osuwania w pozostałych pięciu częściach badanego stoku o odrębnej rzeźbie wykazała, że silne epizody osuwania ( $>20 \%$ opróbowanych drzew zareagowało na osuwanie) wspólne dla więcej niż jednej strefy (obejmujące większą część analizowanego stoku góry Skalka) są nieliczne (Ryc. 7). Należą do nich lata: 1965 (strefy IV i VII), 1975 (V i VII), 1977 (IV i VII) oraz 1993 (V i VII) . Z kolei lata charakterystyczne z silnymi epizodami osuwania ( $>20 \%$ opróbowanych drzew zareagowało na osuwanie), które występują tylko w pojedynczych strefach to (Ryc. 7):

- dla strefy III: 1976, 2004 i 2005,

- dla strefy IV: 1968, 1972 i 1996,

- dla strefy V: 1969-1971, 1985 i 1988,

- dla strefy VI: 1962, 2002,

- dla strefy VII: 1960, 1961, 1968, 1955, 2000, 2008 i 2012 .

Analiza osuwania z podziałem badanej formy na strefy pozwoliła zatem wydatować znacznie więcej silnych epizodów osuwiskowych (22 epizody dla których zareago-

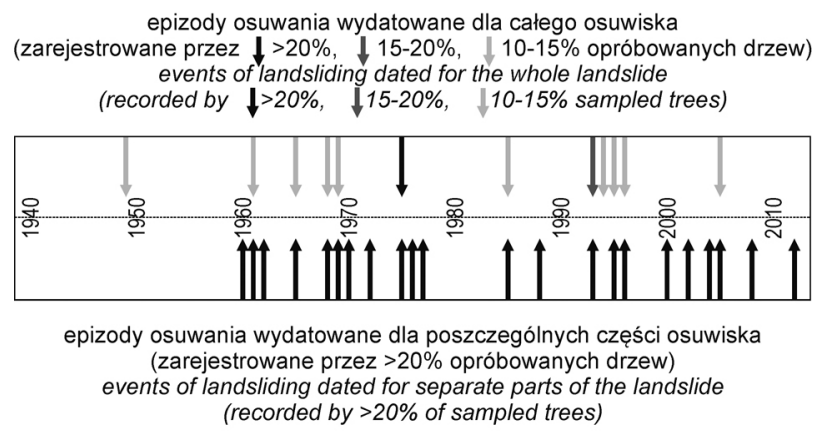

Ryc. 8. Porównanie wyników datowań dendrochronologicznych osuwania uzyskanych dla całego badanego stoku oraz dla poszczególnych jego części (stref morfologicznych)

Fig. 8. Comparison of the dendrochronological results of landsliding obtained for whole studied slopes and for its separate parts (relief zones)

wało $>20 \%$ opróbowanych drzew) (Ryc. 8), niż w przypadku danych dla całego stoku ( 1 epizod $>20 \%$ drzew, 1 epizod 15-20\%, 10 epizodów 10-15\%) (Ryc. 8). Wyniki datowań dendrochronologicznych przedstawiające analizę porównawczą czasu występowania osuwania na badanym stoku ze zdarzeniami opadowymi wskazują, że różne części osuwiska reagowały na opady w różnych latach. Na przykład w latach 1960, 1965, 1975 na wysokie sumy opadów półrocza letniego zareagowały strefy V, VI i VII badanego osuwiska, w roku 1972: III, IV, V i VI, w latach 1977, 1977 i 2010: IV, V i VII, a w roku 1985: II, IV, V, VII (Ryc. 7). W roku 1993, o silnym dendrochronologicznym zapisie osuwania, opadach znacznie poniżej średniej oraz tuż po trzęsieniach ziemi z lat 1992-1993 (Guterch 2009), ruch podłoża zarejestrowały drzewa w strefach: II, III, IV, V i VII (Ryc. 7).

\section{Dyskusja}

Analiza dendrochronologiczna pozwoliła stwierdzić, że badane osuwisko jest aktywne niemal cały czas, jednak w poszczególnych latach, po poszczególnych epizodach opadowych uruchamiane są różne partie badanego stoku. Nie przemieszcza się więc ono raczej jako całość, za wyjątkiem kilku najsilniejszych epizodów, które objęły większą część osuwiska. Podobne obserwacje dotyczące uruchamiania/odmładzania jedynie części stoku osuwiskowego podczas jednego epizodu opisywali także Pánek i in. (2011a, 2011b), Šilhán i in. (2012), Wistuba $\mathrm{i}$ in. (2015). Analizowane osuwisko jest przy tym prawdopodobnie formą o małej intensywności przemieszczania (ang. slow moving landslide). Według badań Noferini $i$ in. (2007) oraz Massey i in. (2013) osuwiska takie mogą przemieszczać się nawet mniej niż centymetr rocznie, jednak w długich okresach czasu nawet tak słabe przemieszczenia mogą mieć znaczenie dla rozwoju rzeźby, a nawet stwarzać zagrożenie dla infrastruktury.

W strefie klimatu umiarkowanego szczególną rolę w przekształcaniu stoków odgrywają ekstremalne opady atmosferyczne (Starkel 2008), powodują nasilenie osu- 
wania i erozji, przez co przyśpieszają transfer materiału w dół stoku (Harvey 2007). Stwierdzono, że aktywność badanego osuwiska można wiązać z wysokimi sumami opadów półrocza letniego. Nie stwierdzono takich zależności dla półrocza zimowego, pomimo, że z literatury znane są przykłady związku katastrofalnego osuwania z opadami wiosennymi (Ziętara 1968). Także Gil i in. (2009) oraz Starkel (2014) wykazali, że osuwanie może być powodowane przez roztopy wiosenne, a według Gorczycy (2008) czynniki wyzwalające osuwanie są złożone i uwzględniają zarówno roztopy wiosenne, wiosenne i letnie opady, długotrwałe opady rozlewne i krótko trwające ulewy. Związek osuwania z opadami półrocza zimowego wykazali także Papciak i in. (2015) stosując metody dendrochronologiczne. Przykłady osuwania wzbudzanego opadami letnimi także są liczne (np. Bajgier-Kowalska 1994, Gorczyca 2008, 2010, Klimeš i in. 2009, Pánek i in. 2011a, 2011b, Wistuba i in. 2014), przy czym efektywność opadów we wzbudzaniu osuwania zależy także od lokalnej rzeźby, pokrywy roślinnej, typu gleby i jej wilgotności w okresie poprzedzającym opad i osuwanie (Margielewski i in. 2008). Datowania uzyskane dla badanego osuwiska w masywie Skalki zgadzają się jednak dobrze z datami uzyskanymi przez Klimeša i in. (2009) dla osuwiska Hluboce (na SW od analizowanego stanowiska) oraz przez Šilhána i in. (2013) dla osuwiska Mazák (11 km na NW od badanego stoku), a w przypadku silnych epizodów nawet z datowaniami aktywności osuwiska „L. Sawickiego" w Beskidzie Niskim uzyskanymi przez Nawrocką (2013).

Wśród wydatowanych na badanym stoku epizodów osuwania stwierdzono także przemieszczenia koluwiów w okresach suchych, w roku 1993 oraz równie suchym roku 1992. Wydaje się, że czynnikiem uaktywniającym osuwania w tym przypadku mogły być trzęsienia ziemi z lat 1992-1993 (Guterch 2009). Znaczenie wstrząsów sejsmicznych dla uruchamiania osuwisk w Karpatach opisywał Rączkowski (2007), a Gerlach i in. (1958) oraz Papciak i in. (2015) udokumentowali aktywność osuwisk w Beskidzie Niskim w związku z trzęsieniem ziemi w 1957 roku. Ponieważ dolna część badanego osuwiska w masywie Skalki jest wyraźnie podcinana przez potok, który płynie u jego podnóża, dodatkowym czynnikiem uaktywniającym osuwania może być także erozja boczna destabilizująca stok. Przykłady takie znane są z literatury (np. Azañon i in. 2005, Lévy i in. 2012, Wistuba i in. 2015), jednak aby wykazać także zależność w przypadku badanego stoku konieczne byłoby pozyskanie bezpośrednich danych pomiarowych o przepływach w korycie potoku lub danych pośrednich do rekonstrukcji przebiegu erozji - np. danych dendrochronologicznych (Wistuba $\mathrm{i}$ in. 2015).

Porównanie wyników badań uzyskanych dla badanego osuwiska jako całości oraz dla poszczególnych jego części pozwoliło w tym drugim przypadku uzyskać informacje o znacznie większej liczbie epizodów osuwania. Epizody wyznaczone na podstawie danych zebranych dla całej badanej powierzchni można uznać za zdarzenia, w czasie których nieznacznemu przemieszczeniu uległ cały badany stok lub jego większa część. Natomiast epizody wyznaczone w oparciu o dane dla jednej - dwóch stref morfologicznych badanego osuwiska można uznać za przemieszczenia o bardzo ograniczonym zasięgu przestrzennym, ale być może o większym natężeniu ruchu. $\mathrm{W}$ analizach dendrochronologicznych czasowej zmienności osuwania na ogół stoki osuwiskowe traktowane są jako całość, bez uwzględniania ich zróżnicowania morfologicznego, które może przekładać się na zróżnicowanie nie tylko w przebiegu (częstotliwości, prędkości) ruchu koluwiów, ale także parametrów takich jak głębokość czy kształt płaszczyzny poślizgu, a nawet na zróżnicowanie czynników uaktywniających osuwania w różnych częściach stoku. Może to mieć miejsce nie tylko w przypadku dużych osuwisk o złożonej budowie i rzeźbie, ale także w przypadku form mniejszych. Wistuba i in. (2013a) stwierdzili, że w przypadku niewielkich osuwisk zboczowych osuwanie w górnej części stoku może być wzbudzane przez opady, a w dolnych częściach tych samych form przez erozję cieków zaburzających stabilność stoków.

Traktowanie złożonych form osuwiskowych jako całości może w przypadku rekonstrukcji dendrochronologicznych zaburzać uzyskiwane wyniki. Na przykład Pánek $\mathrm{i}$ in. (2011a) oraz Malik i Wistuba (2012) zaobserwowali wyraźne rozbieżności w zapisie osuwania i w przebiegu opadów. Z tego względu analiza uzyskiwanych metodą dendrochronologiczną wyników zarówno dla całego stoku, jak i dla poszczególnych jego części wydaje się właściwym podejściem. Pozwala to wychwycić większą liczbę epizodów ruchu oraz uzyskać dodatkowe informacje o ich zasięgu przestrzennym, jak w przypadku badanego osuwiska w masywie Skalka oraz w niektórych przykładach dotąd publikowanych badań (np. Šilhán 2012).

\section{Wnioski}

1. Badane osuwisko przemieszcza się powoli. W poszczególnych latach uruchamiane są różne partie badanego stoku.

2. Relatywnie silne epizody osuwania rzadko obejmują jednocześnie więcej niż jedną z wydzielonych stref morfologicznych badanego stoku.

3. Analizując przebieg osuwania oddzielnie, w poszczególnych strefach morfologicznych badanego stoku, uzyskano pełniejszy obraz epizodów ruchu. Wydatowano epizody, których nie wykryto analizując osuwisko jako całość.

4. Epizody wyznaczone na podstawie danych zebranych dla całej badanej powierzchni można uznać za zdarzenia, w czasie których nieznacznemu przemieszczeniu uległ cały badany stok lub jego większa część. Natomiast epizody wyznaczone w oparciu o dane dla jednej - dwóch stref morfologicznych badanego osuwiska można uznać za przemieszczenia o bardzo ograniczonym zasięgu przestrzennym, a być może większym natężeniu ruchu. 
5. Połączona analiza osuwiska jako całości i poszczególnych jego części jest dobrym podejściem metodycznym, ponieważ pozwala w sposób pełniejszy zrekonstruować liczbę epizodów ruchu koluwium oraz uzyskać dodatkowe informacje o ich zasięgu przestrzennym.

6. Osuwanie na badanym stoku wydaje się być w dużym stopniu zależne od występowania wysokich opadów półrocza letniego. Podobnej zależności nie stwierdzono dla opadów półrocza zimowego.

7. Dodatkowym czynnikiem uaktywniającym w przypadku badanego osuwiska mogły być wstrząsy sejsmiczne z lat 1992-1993 o epicentrach położonych w Beskidzie Sąeckim. W 1993 roku stwierdzono dużą aktywność badanej formy mimo niewielkich opadów.

\section{Podziękowania}

Badania zrealizowano $\mathrm{W}$ ramach projektu OPUS 2011/01/B/ST10/07096 finansowanego przez Narodowe Centrum Nauki. Podczas przygotowywania publikacji do druku jedna z autorek - Małgorzata Wistuba - była stypendystką Fundacji na Rzecz Nauki Polskiej (stypendium START na lata 2015-2016).

\section{Udzial autorów}

Katarzyna Łuszczyńska jest odpowiedzialna za koncepcję i napisanie artykułu, zebranie, analizę i interpretację danych. Małgorzata Wistuba jest odpowiedzialna za koncepcję artykułu, interpretację danych, korektę artykułu i ostateczną aprobatę artykułu do opublikowania.

\section{Literatura}

Azañon J.M., Azor A., Pérez-Peña J.V., Carrillo J.M., 2005. Late Quaternary large-scale ratational slides inducted by river incision: The Arroyo de Gor area (Guadix basin, SE Spain). Geomorphology 69: $152-168$.

Bajgier-Kowalska M., 1994. Rozwój osuwisk w czołowej strefie płaszczowiny magurskiej w dorzeczu górnej Soły. Przegląd Geograficzny 66(3-4): 375-388.

Braam R.R., Weiss E.E.J., Burrough, P.A., 1987. Spatial and temporal analysis of mass movement using dendrochronology. Catena 9: 573-584.

Gerlach T., Pokorny J., Wolnik R., 1958. Osuwisko w Lipowicy. Przegląd Geograficzny 30(4): 685-698.

Gil E., Zabuski L., Mrozek T., 2009. Hydrometeorological conditions and their relation to landslide processes in the Polish flysch Carpathians (an example of Szymbark area). Studia Geomorphologica Carpatho-Balcanica 43: 127-143.

Gorczyca E., 2008. Rola płytkich ruchów osuwiskowych w kształtowaniu stoków fliszowych (na przykładzie Beskidu Wyspowego i Bieszczadów). Przegląd Geograficzny 80(1): 105-126.

Gorczyca E., 2010. Slope relaxation following landslides in the Lososina River Basin, Beskid Wyspowy Mts., Poland. Landform Analysis 14: 3-11.

Guterch B., 2009. Sejsmiczność Polski w świetle danych historycznych. Przegląd Geologiczny 57: 513-520.
Harvey A.M., 2007. Differential recovery from the effects of a 100-year storm: Significance of long-term hillslope channel coupling; Howgill Fells, northwest England. Geomorphology 84: 192-208.

Hess M., 1965. Piętra klimatyczne w Polskich Karpatach Zachodnich, Zeszyty Naukowe Uniwersytetu Jagiellońskiego. Prace Geograficzne 11, Kraków.

Interactive Geological Maps of the Czech Republic, 2003. 1:25 000, DVD-ROM. Czech Geological Survey, Prague.

Klimeš J., Baroň I., Pánek T., Kosačík T., Burda J., Kresta F., Hradecký J., 2009. Investigation of recent catastrophic landslides in the flysch belt of Outer Western Carpathians (Czech Republic): progress towards better hazard assessment. Nat. Hazards Earth Syst. Sci. 9: 119-128.

Klimeš J., Blahůt J., 2012. Landslide risk analysis and its application in regional planning: an example from the highlands of the Outer Western Carpathians, Czech Republic. Natural Hazards 64(2): 17791803

Krapiec M., Margielewski W., 1991. Zastosowanie analizy dendrogeomorfologicznej w datowaniu powierzchniowych ruchów masowych. Kwartalnik AGH - Geologia 17(1-2): 67-81.

Krąpiec M., Margielewski W., 2000. Analiza dendrogeomorfologiczna ruchów masowych na obszarze polskich Karpat fliszowych. Kwartalnik AGH Geologia 26(2): 141-171.

Krąpiec M., Rączkowski W., Danek M., Kłusek M., Gil E., Zabuski L., 2008. Monitoring dendrogeomorfologiczny osuwisk w Beskidzie Niskim. Prace Komisji Paleogeografii i Czwartorzędu PAU 6: 173-184.

Lang A., Moya J., Corominas J., Schrott L., Dikau R., 1999. Classic and new dating methods for assessing the temporal occurrence of mass movements. Geomorphology 30: 33-52.

Lévy S., Jaboyedoff M., Locat J., Demers D., 2012. Erosion and channel change as factors of landslide and valley formation in Champlain Sea Clays: The Chacoura River, Quebec, Canada. Geomorphology 145-146: 12-18.

Lopez Saez J., Corona C., Stoffel M., Schoeneich P., Berger F., 2012. Probability maps of landslide reactivation derived from tree-ring records: Pra Bellon landslide, southern French Alps. Geomorphology 138: 189-202.

Malik I., 2008. Dendrochronologiczny zapis współczesnych procesów rzeźbotwórczych kształtujących stoki i doliny rzeczne wybranych stref krajobrazowych Europy Środkowej. Wyd. UŚ, Katowice.

Malik I., Wistuba M., 2012. Dendrochronological methods for reconstructing mass movements - landslide activity analysis using tree-ring eccentricity. Geochronometria 39(3): 180-196.

Margielewski W., 1997. Dated landslides of the Jaworzyna Krynicka range (Polish Outer Carpathians) and their relations to climatic phases of the Holocene. Annales Socirtatis Geologorum Poloniae 67: 83-92.

Margielewski W., Święchowicz J., Starkel L., Łajczak A., Pietrzak M., 2008. Współczesna ewolucja rzeźby Karpat fliszowych. W: L.Starkel (red.), Współczesne przemiany rzeźby Polski. Instytut Geografii i Gospodarki Przestrzennej UJ, Kraków: 57-133.

Massey C.I., Petley D.N., McSaveney M.J., 2013. Patterns of movement in reactivated landslides. Engineering Geology 159: 1-19.

Nawrocka N., 2013. Analiza dendrogeomorfologiczna drzew różnych gatunków z obszaru osuwiska „L. Sawickiego”w Szymbarku, Beskid Niski, Karpaty Zewnętrzne. Folia Quaternaria 81.

Noferini L., Pieraccini M., Mecatti D., Macaluso G., Atzeni C., Mantovani M., Marcato G., Pasuto A., Silvano S., Tagliavini F., 2007. Using GB-SAR technique to monitor slow moving landslide. Engineering Geology 95 (3-4): 88-98.

Pánek T., Brázdil R., Klimeš J., Smolková V., Hradecký J., Zahradníček P., 2011a. Rainfallinduced landslide event of May 2010 in the eastern part of the Czech Republic. Landslides 8: 507-516.

Pánek T., Šilhán K., Táboř́k P., Hradecký J., Smolková V., Lenart J., Brázdil R., Kašičková L., Pazduri A., 2011b. Catastrophic slope failure and its origins: Case of the May 2010 Girová Mountain long-runout rockslide (Czech Republic). Geomorphology 130: 352-364.

Papciak T., Malik I., Krzemień K., Wistuba M., Gorczyca E., Wrońska-Wałach D., Sobucki M., 2015. Precipitation as a factor triggering landslide activity in the Kamień massif (Beskid Niski Mts, Western Carpathians). Bulletin of Geography. Physical Geography Series 8: $5-17$. 
Raczkowski W., 2007. Landslide hazard in the Polish Flysch Carpathians. Studia Geomorphologica Carpatho-Balcanica 41: 61-75.

Schweingruber F.H., 1996. Tree Rings and Environment. Dendroecology, Birmensdorf, Swiss Federal Institute for Forest, Snow and Landscape Research, Berne, Stuttgart, Vienna, 272.

Seneta W., Dolatowski J., 2008. Dendrologia, PWN, Warszawa.

Shroder J.F., 1980. Dendrogeomorphology: review and new techniques of tree-ring dating. Progress in Physical Geography 4: 161-188.

Šilhán K., 2012. Dendrogeomorphological analysis of the evolution of slope processes on the flysch rocks (Vsetínské Vrchy MTS., Czech Republic).

Šilhán K., Pánek T., Hradecký J., 2012. Tree-ring analysis in the reconstruction of slope instabilities associated with earthquakes and precipitation (the Crimean Mountains, Ukraine): Geomorphology 173-174: 174-184.

Šilhán K., Pánek T., Dušek R., Havlů D., Brázdil R., Kašičková L., Hradecký J., 2013. Dating of bedrock landslide reactivations using dendrogeomorphic techniques: the Mazák landslide, Outer Western Carpathians (Czech Republic). Catena 104: 1-13.

Šilhán K., Pánek T., Turský O., Brázdil R., Klimeš J., Kašičková L, 2014. Spatio-temporal patterns of recurrent slope instabilities affecting undercut slopes in flysch: A dendrogeomorphic approach using broad-leaved trees. Geomorphology 213: 240-254.

Starkel L., 2008. Rola ekstremalnych zjawisk meteorologicznych w przekształcaniu rzeźby południowej Polski. W: M.J.Kotarba (red.), Przemiany środowiska naturalnego a rozwój zrównoważony. Wyd. TBPŚ GEOSFERA, Kraków: 41-52.
Starkel L., 2014. O niektórych prawidłowościach rozwoju rzeźby gór i ich przedpoli. Instytut Geografii i Przestrzennego Zagospodarowania PAN, Wydawnictwo Akademickie "Sedno", Warszawa: 71-115.

Štekl I., Brázdil R., Kakos V., Jež J., Tolasz R., Sokol Z., 2001. Extrémní denní stážkové úhrny na území ČR vobdobí 1879-2000 a jejich synoptické př́íčiny. Národní klimatický program České republiky 31, Praha.

Wistuba M., Malik I., 2011. Indeks dekoncentryczności przyrostów rocznych drzew - narzędzie do identyfikacji współczesnych ruchów osuwiskowych. Czasopismo Geograficzne 82(4): 401-421.

Wistuba M., Malik I., Fajer M., Papciak T., 2013a. Dendrochronological record of coupling between landslides and eroding stream channel (Western Outer Carpathians, Czech Republic). Studia Geomorphologica Carpatho-Balcanica 47.

Wistuba M., Malik I., Gärtner H., Kojs P., Owczarek P., 2013b. Application of eccentric growth of trees as a tool for landslide analyses: The example of Picea abies Karst. in the Carpathian and Sudeten Mountains (Central Europe). Catena 111: 41-55.

Wistuba M., Malik I., Polowy M., Michałowicz P., 2014. Zastosowanie dekoncentryczności przyrostów rocznych w badaniach stoku o wysokim zagrożeniu osuwiskowym (Milówka, Beskid Żywiecki). Studia i Materiały Centrum Edukacji Przyrodniczo-Leśnej.

Wistuba M., Malik I., Wójcicki K., Michałowicz P., 2015. Coupling between landslides and eroding stream channels reconstructed from spruce tree rings (examples from the Carpathians and Sudetes - Central Europe). Earth Surface Processes and Landforms 40(3): 293-312.

Ziętara T., 1968. Rola gwałtownych ulew i powodzi w modelowaniu rzeźby Beskidów. Prace Geograficzne PAN 60. 